\title{
Collaborative Governance in Tourism Development in Indonesia: Study of South Sumatera Province
}

\author{
Irene Camelyn Sinaga \\ Pancasila Ideology Development Agency, Republic of Indonesia
}

\begin{abstract}
Received: Jun. 13, 2021 Accepted: Jul. 26, $2021 \quad$ Online published: Aug. 3, 2021
doi:10.5296/jpag.v11i3.18747～URL: https://doi.org/10.5296/jpag.v11i3.18747
\end{abstract}

\begin{abstract}
Tourism is a potential sector in the development of an area with very minimal risk of environmental damage, this makes tourism the leading sector in all regions, including the province of South Sumatra. In a normative and empirical process, tourism development needs to be done through collaborative management, this is because tourism has multidimensional characteristics. South Sumatra Province with the potential it has and is supported by Brand Sport Tourism, it turns out that the development process is still being carried out separately between all parties involved, this has made tourism development in South Sumatra Province still not optimal. This research uses Collaborative Governance theory proposed by Ansell \& Gash which can be seen from 4 (four) dimensions, namely initial conditions, facilitative leadership, institutional design, and the collaboration process. The research approach used in this research is a qualitative approach with descriptive research type. The data analysis technique used is data reduction and conclusion drawing. The results of the study indicate that the ongoing tourism development process has not yet fully adopted collaborative governance. This is because trust has not been formed in each of the actors involved.
\end{abstract}

Keywords: collaborative governance, tourism development, actors web

\section{Introduction}

According to the World Tourism Organization (WTO), tourism is the largest industry in the world. Tourism in fact has an important role in the national and regional economies. Many countries have made tourism a mainstay sector driving the economy, because tourism was proven to be able to create employment in very large numbers in 2006, for example, this sector generated 10.3 percent of total GDP ( Gross Domestic Product) of the world. The World Travel and Tourism Council (WTTC) reports that the tourism sector remains the largest industry in the world by contributing 10.4 percent Gross Domestic Product in 2017 through dynamics as shown in the following table: 
Table 1. Breakdown of travel \& Tourism's Total Contribution to GDP

\begin{tabular}{|l|l|l|l|l|}
\hline \multirow{2}{*}{\multicolumn{1}{c|}{ Description }} & \multicolumn{3}{c|}{ Year } & \multirow{2}{*}{ Average } \\
\cline { 2 - 5 } & $\mathbf{2 0 1 5}$ & $\mathbf{2 0 1 6}$ & $\mathbf{2 0 1 7}$ & \\
\hline Direct & 34.3 & 29.4 & 33 & 32.23 \\
\hline Indirect & 44.1 & 48.6 & 45.1 & 45.93 \\
\hline Induced & 21.6 & 22 & 21.9 & 21.83 \\
\hline Total & 100 & 100 & 100 & 100 \\
\hline
\end{tabular}

Source: World Travel \& Tourism Council, 2020.

Based on the data above, it can be seen that the indirect contribution of tourism provides the largest contribution with an average percentage of 45.93 percent, while the direct influence (direct) with a percentage of 32.23 percent and an average induced contribution of 21.83 percent, with a total relative contribution as a whole in Asia Pacific countries as illustrated in the following table:

Table 2. Data on the Relative Contribution of Travel and Tourism to Asia Pacific GDP in 2015-2017

\begin{tabular}{|l|l|l|l|l|}
\hline \multirow{2}{*}{ No. } & \multirow{2}{*}{ Country } & \multicolumn{3}{c|}{ Year in Percent } \\
\cline { 3 - 5 } & & $\mathbf{2 0 1 5}$ & $\mathbf{2 0 1 6}$ & \multicolumn{1}{|c|}{$\mathbf{2 0 1 7}$} \\
\hline 1 & China & 7.9 & 9 & 11 \\
\hline 2 & India & 6.3 & 9.6 & 9.4 \\
\hline 3 & Thailand & 20.8 & 20.6 & 21.2 \\
\hline 4 & Australia & 10.8 & 10.9 & 11 \\
\hline 5 & Indonesia & 9.6 & 6.2 & 5.8 \\
\hline 6 & Malaysia & 13.1 & 13.7 & 13.4 \\
\hline Average & & 9.8 & 10.2 & 10.4 \\
\hline
\end{tabular}

Source: World Travel \& Tourism Council, 2020.

The data above illustrates that the total contribution of world tourism to GDP has increased from 9.8 percent in 2015 to 10.40 percent in 2017. In line with world development, Thailand has also received the largest contribution above the world's average contribution when compared to other countries. another with a contribution amount of 20.87 percent. A different thing was experienced by Indonesia, which experienced a decrease in the contribution of the tourism sector to GDP in 2015 by 9.6 percent, experiencing a decrease in 2016 by 6.2 percent and becoming 5.8 percent in 2017.

Tourism is considered an economic solution for former socialist countries in Eastern Europe, East Asia and for many underdeveloped countries. In fact, the tourism industry, which is both a job creator and a substitute for limited capital by producing tourism services, may be coercive for people who for the first time in half a century are facing the problem of rising unemployment. The contribution to the macro economy mentioned above also has a social contribution, especially in the creation of employment opportunities which is illustrated in the 
following table:

Table 3. Data on the Relative Contribution of Travel and Tourism to the Employment of Asia Pacific Countries 2015-2017

\begin{tabular}{|c|l|c|c|c|}
\hline \multirow{2}{*}{ No. } & \multirow{2}{*}{ Country } & \multicolumn{3}{|c|}{ Year } \\
\cline { 3 - 5 } & & $\mathbf{2 0 1 5}$ & $\mathbf{2 0 1 6}$ & $\mathbf{2 0 1 7}$ \\
\hline 1 & China & 8.4 & 9 & 10.3 \\
\hline 2 & India & 8.7 & 9.3 & 8 \\
\hline 3 & Thailand & 15.4 & 15.1 & 15.5 \\
\hline 4 & Australia & 12.6 & 12.5 & 12.2 \\
\hline 5 & Indonesia & 8.7 & 5.6 & 10 \\
\hline 6 & Malaysia & 11.4 & 12 & 11.8 \\
\hline World Average & $\mathbf{9 . 5}$ & $\mathbf{9 . 6}$ & $\mathbf{9 . 9}$ \\
\hline
\end{tabular}

Source: World Travel \& Tourism Council, 2020

Based on the table above, it can be seen that the contribution to overall job creation in the world in 2015 to 2017 was 9.66 percent. The data above also explains that the contribution to employment in Indonesia was the highest in 2017 at 10 percent. This illustrates that even though the contribution of tourism to GDP has decreased, it does not have an impact on employment, which has increased by 4.4 percent compared to 2016 . This explanation is in line with the opinion of Peck and Lepie (Peck \& Lepie, 1989) which explains that "The nature of tourism in any society is the product of interrelated but complex economic, political factors, and also have certain geographical characteristics and all of which are attractive to the "outsiders" of the place". In line with this, the condition of Indonesia's tourism competitiveness, which has increased its position from rank 70 in 2013 to rank 50 in 2015.

The Ministry of Tourism has determined the tourism sector to be the core business of the national economy in terms of export income, job creation, company development and regional infrastructure development. The vital role of the tourism sector requires all parties or stakeholders to develop this sector in a sustainable manner. In addition to the important role and positive impact generated by the tourism sector, this sector also has a negative impact on destinations. If it is not managed with sustainable principles, the tourism sector can have a negative impact on local communities, the natural environment, and the economy as part of Indonesia's development priorities through one of the national targets announced, namely 20 million foreign tourist visits in 2019, this target is faced with its importance. planning as an important element that must be considered carefully and responsibly in order to be able to control the resulting environmental and cultural impacts.

The importance of planning as described above in tourism development is reflected in the mandate of Article 1 paragraph 4 of Law No. 10 of 2009 on Tourism which explains that "Tourism is all activities related to tourism and is multidimensional and multidisciplinary ...". Natori emphasized that tourism-based community development is very important when the community must be involved in developing the area they own (Natori, 2001). Community 
involvement is a form of high enthusiasm in improving the quality of its own life (enthusiasm for community development). The hope of improving the quality of life of the community which is the dream of all governments, including the South Sumatra Provincial Government, makes the management of the authority delegated by the government to be carried out as well as possible.

The handover of government affairs in the tourism sector in South Sumatra Province is one of the priority matters of choice considering that the expansion of technology-based local and international tourism networks and cooperation is an opportunity for regional development to create employment opportunities in line with the 2013-2018 Vision, namely: "South Sumatra is Prosperous, More advanced and internationally competitive". Regional autonomy will run if the ability of the region (self-help financing) is strong enough, considering that the province of South Sumatra has the potential for natural, historical, culinary and cultural tourism. The advantages of decentralization of tourism policies are in the spirit of regional autonomy, then the regions are directed to mobilize tourism to contribute to Regional Original Income.

The implementation of the principle of decentralization in tourism management through a decentralized government can move the 'marginalization' decision, this means giving flexibility to tourists, communities, businesses and self-help groups to interact mutually advantageously in destination areas that become their authority. Meanwhile, pressing the 'downward' decision contains the interpretation that public authorities at lower levels are encouraged to provide the best service to the public. This is possible if participatory management and teamwork organizational models are consistently practiced by a decentralized entrepreneurial government.

In the practice of decentralization for tourism development in the lowest hierarchical destinations, there are still quite a number of obstacles, namely:

1. Dualism in law enforcement regulations in the tourism sector between bureaucratic institutions applies Law No.10 / 2009

2. Limited authority and understanding of local government officials in elaborating Law no. 32/2004 and the revision of Law No.23/2014 on Regional Government.

3. Less / unknown tourism anatomy by tax collection agencies (Bapenda), both provincial and district / city.

4. Weak legal definition regarding law enforcement efforts in the tourism sector, both in Law No.10 / 2009 and in implementing regulations at the Kepmen and Kepdirjen levels.

5. Lack of firmness in the application and implementation of regional regulations in an effort to collect taxes on tourism-related sectors in the region.

6. Particularly in the framework of regional autonomy, Regency / City Tourism Offices have not been fully formed as the implementing agencies of authority which can be used as tax objects in the tourism sector.

7. Increasing the role of implementing agencies to become stimulators and facilitators of unpromising tourism multiproduct nurseries. 


\section{MlMacrothink}

Journal of Public Administration and Governance ISSN 2161-7104 2021, Vol. 11, No. 3

The seven obstacles mentioned above, as a whole illustrate that tourism management which concretely requires synergy between sectors has not been running well in accordance with their duties and functions, but in fact each actor in tourism management still has their own point of view. The importance of this synergy is also closely related to the challenges in the issue of allocation of limited resources to the government to meet the needs and desires of citizens which are not only diverse, but also conflicting (Gabriel, 2017). This phenomenon is actually the impact of the slow adjustment that occurs in the government in accordance with the rapid changes faced by society.

The development of the phenomenon of government that changes the position of government that has a dominant role and has a single responsibility to become more fused with roles that are divided into two perspectives, namely: first, the opening of space for the involvement of the private sector and civil society in the process of formulating policies and activities in the production of services and goods. In meeting the needs of the community to be more empowered, direct interaction between tourists and tourism management objects requires civil and empowered tourism actors, so that the satisfaction expected by tourists can be fulfilled directly. Second, this point of view is seen more from the public's distrust of the government which has difficulty in changing the culture it adheres to in carrying out convoluted tasks and functions, making it difficult to become a professional organization. This point of view clearly hinders the management of tourism as an industry that demands the professionalism of every actor involved.

\section{Method}

This study uses a post-Positivism research paradigm with a deductive-qualitative approach. Determination of informants in research using purposive sampling technique, namely informants are selected with certain considerations and goals (Maxwell, 2012). The informants in this study consisted of local governments and communities. Local Government is a formal institution that is closely related to tourism development.

\section{Result and Discussion}

\section{Tourism Development Based on Collaborative Governance in South Sumatra Province}

The development of tourism in the province of South Sumatra has a huge opportunity for the economic development of the community, and has a close relationship with cultural preservation. This strategic role is cross-sectoral which will have overall implications for the socio-political sector, government, defense and security, economic development and culture. Various developments that occur in the province of South Sumatra can not be separated from its relationship with the development of tourism. Various tourism potentials in South Sumatra Province were developed by dealing with various problems and emerging issues related to changes resulting from specific tourism developments. This is in line with the opinion of research informants who stated that: "Because of the importance of Tourism in the development of South Sumatra Province, the Tourism sector has become a Leading Sector which is described in Regional Strategic Policies in various Sectors, there are Regional Development Sector, Cultural Development Sector, and Environmental Sector Development. 
Tourism development in South Sumatra Province with the spirit of "Returning Sriwijaya's past glory" is not easy to achieve without collaboration. Collaboration starting from planning, development, management, evaluation of achievements to the benefits of Collaboration. The hope of developing tourism from time to time can be seen from the efforts made by the Government by raising public awareness and stakeholders who have an important role in the world of tourism. In reality, the government cannot develop tourism without involving other parties. This is not only because tourism development requires large financial resources but also human and natural resources that must match the expectations of development achievements. The commitment of the Regional Government which still looks ambiguous can be seen from the minimal government budget allocation for the tourism sector, which amounts to $0.8 \%$ of the total budget of the South Sumatra Provincial Government.

The achievement of optimal tourism development in South Sumatra can be achieved through the division of roles in collaboration so that all stakeholders are actively involved and generate a sense of responsibility in tourism together. This is shown in 2018 when Pesona Sriwijaya was formed as a forum to accommodate the involvement of all interested actors in South Sumatra Province.

The important role of tourism, urgently requires the involvement of every element and sector to work together synergistically in pursuing an effective and efficient tourism development model based on the culture and potential resources possessed by the Province of South Sumatra. The linkage of various sectors with tourism that occurred in the province of South Sumatra, for example in 2013 with the separation of Panukal Abab Lematang Ilir Regency from Muara Enim Regency and the separation of North Musi Rawas Regency from Musi Rawas Regency prepared a comprehensive change in tourist attraction assets which has become a provincial policy. in developing its tourism potential. Considering the development of tourism in South Sumatra Province which is experiencing rapid development, it is very necessary to have very good quality tourism quality, this is because tourist interest has increased as a consequence of the development of information technology. For this reason, joint collaboration between all interested parties, including the Government, Private Parties, Community and Non-Governmental Organizations, is needed to jointly create quality tourism products.

The development of tourism quality is highly dependent on the shift in tourist trand or the interest of tourists in particular towards tourist objects as tourist destinations. Conventionally, the development of tourism can be grouped into $4 \mathrm{~S}$ (Snown, Sun, Sand and Sea). The grouping of tourist objects is based on the trend that has developed as a tourist destination which has become a tourist destination. $4 \mathrm{~S}$ is a popular interest for tourists, because these objects contain aspects that interact directly with tourists in a very deep physical and emotional self-development with natural elements and local communities at the same time so as to provide a memorable experience for tourists.

This is in line with the mandate of Law Number 10 of 2009 concerning Tourism which explains "Tourism as a travel activity carried out by a person or group of people by visiting 
certain places for recreational purposes, personal experiences, or learning the uniqueness of tourist attractions in a temporary period" . Based on this understanding, tourism which is paired with the word tourism must be interpreted as a very broad system with links including tourists, tourist destinations and efforts to connect tourists with tourist objects.

Related to the various efforts to connect tourists with tourist destinations, the discussion in the next sub-chapter will explain the results of research and discussions related to the concept of Collaborative Governance as the concept used in this study (Ansell \& Gash, 2008). This meaning is in line with the view of Governance as a Network which understands:

Governance are institutions and actors who come from and also not only from the government because of the limits of government responsibility in dealing with social and economic issues, each institution depends on one another and there is no command authority from the government. Networks are a general form of social coordination and organizational linkage patterns in the private or public sector and as a mechanism for coordinating and allocating resources as a form of governing, in the same way markets or bureaucracies do. In this case Networks is not an alternative, not a hybrid of markets and hierarchies.

As an effort to connect tourists with tourism objects as the potential of the South Sumatra region, it is discussed in the context of developing tourism networking as an industry that drives various regional sectors. in the concept of tourism, there are several terms that are often used as an integral part of describing tourism activities, including: tourism, tourism and tourism. Tourism is a concept related to the complexity of carrying out tourism activities and contributing to the tourism sector economically within a certain period of time.

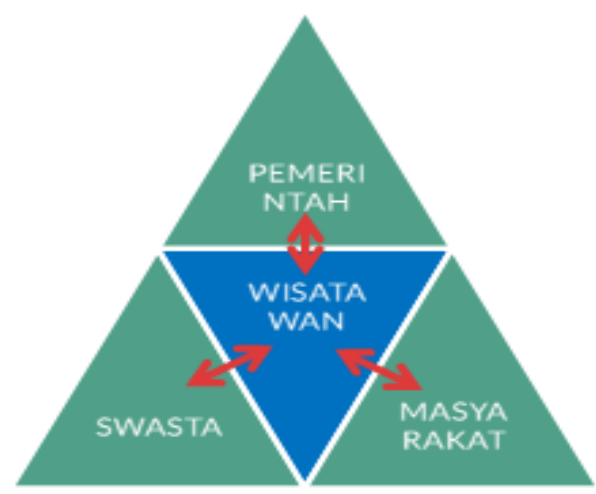

Keseluruh stakeholders pariwisata tersebut harus terlibat secara aktif dan
saling mendukung dalam suatu sinergi dalam melaksanakan pembangunan
kepariwisataan di Provinsi Sumatera Selatan. Untuk itu proses dan bentuk

Source: author, 2021.

As a tourism system, it is a series of activities that connect various sectors, both economic, social and environmental. Goeldner and Richie define tourism as "the accumulation of phenomena and relationships that grow from the interaction of tourists, business actors 
providing goods and services, government and local communities in the process of attracting and hosting a number of tourists and other visitors" (Goedner \& Ritchie, 2011). The actualization of this definition can be seen briefly in the following image:

Tourism development has evolved to engage, respond to, and be accountable to those directly affected by its implementation, social and human development objectives have been given greater consideration. Consequently, the goal of sustainable tourism is to better adapt to the unique features of the local context and culture. This locally oriented development approach requires better advantage of the talent and broad experience of the local community as well as interaction and collaboration on existing social networks. This can help strengthen local community cohesion, share the past, and the history of participation in social action during times of uncertainty and change (Goedner \& Ritchie, 2011).

The concept of collaborative tourism development is also formally contained in Law Number 10 of 2009 concerning Tourism which defines tourism as "all activities related to tourism and have a multidimensional and multidisciplinary nature that appears as a manifestation of the needs of every person and country as well as interactions between tourists and the community. local, fellow tourists, government, local government and businessmen. This is as stated by Research Informants that:

The government collaborates with tourism because we are taught to pentahelix. Seeing tourism, there is enough development in the sense of the word development, not only this but times changing government policies have also changed, now to a situation where our minister once declared the pentahelix.

Collaborative Governance is a model that brings together public and private stakeholders in a collective forum with public institutions to be involved in consensus decision making. In other words, Collaborative Governance is a controlling arrangement in which one or more public institutions and non-state stakeholders are directly involved in formal, consensus-oriented, deliberative collective decision-making processes that aim to make or implement public policies, manage programs or public assets.

\section{a. Starting Condition}

Based on various literatures, it is revealed that many collaboration processes fail due to differences in views between stakeholders and stakeholders, these differences in views are based on the bitter experiences experienced by stakeholders. This experience occurred because the identification of the initial conditions for the formation of collaboration was not based on facts and data from each stakeholder.

The absence of openness from each stakeholder will trigger the emergence of local emotional issues that affect trust and mutual suspicion of one another, resulting in an assumption of mutual hostility. This condition will create an atmosphere of collaboration followed by a sense of suspicion, considering the collaboration in the tourism industry which is more highlighted is the financial impact for all stakeholders. It is this profit orientation that makes every actor do not want to experience a loss of capital that has been invested in the 
collaboration process. Tourism as an industry that is growing, developing and has promising prospects, both regionally and internationally, can be considered as a new opportunity for the growth and development of related business sectors.

Tourism as a liaison for economic and social aspects in its development is a series of activities that are centered on the activities of tourists who enjoy the charm of natural, artificial, historical and cultural attractions, as a tourism service industry is very dependent on the attraction to be enjoyed by tourists. socially interaction between humans occurs, there is also a cultural learning process as a consequence of the interaction between individuals. In particular, sustainable tourism can have an important positive impact on the quality of life of the poor in developing countries, offering possibilities for poverty reduction as well as social and human development.

Tourism itself is actually an industry that has close links with other sectors, such as education, culture, technology, trade and industry, banking, and security. This linkage can take the form of the provision of products and services needed in tourism activities (tourist products) or it can be called a direct relationship, as well as in the form of indirect linkages such as the development of craftsmen carried out by agencies outside tourism, or the expansion and repair of roads carried out by the Public Works Agency and other forms. Meanwhile, to see the opportunity to create a tourism business partnership program, it can be explored by looking at the chain of tourism activities that occur in an area. In this case, limiting observations based on geography (area) is important considering that the chain that occurs is influenced by the level of intensity of tourism activities, the level of tourism growth, and the local potentials that are owned are different from one region to another.

The collaboration process as referred to by Ansell and Gash requires a balance of resources between each actor and also the object of collaboration, this is very important to create dependence between stakeholders in order to maintain relationships in collaboration. In addition, resources for the object of collaboration are also important because in tourism the selling value that is highlighted is the tourist attraction. In addition, there are views from research informants who state that:

One thing that prioritizes sustainability rather than tourism itself, economically, investment, environmentally, etc., I agree with the pentahelix element because if we look backwards when tourism development with components that really need to be $3 \mathrm{~A}$ and $4 \mathrm{P}$ elements, there are accessibility, amenities, attractions, and supported by the existence of products, physical, people, programs, in tourism development. The view mentioned above, explains that the complexity of tourism development has its own challenges. This is shown by many interrelated and supportive aspects in tourism development. In the context of $3 \mathrm{~A}$ and $4 \mathrm{P}$, it is intended to show the dependence of tourism not only on tourism objects, but also other aspects of facilities and infrastructure that support the sustainability of tourism activities.

b. Institutional Design

Institutional design as the first step in implementing collaborative governance is a joint decision that is realized and deliberated by all interested actors. Considering in the concept of collaborative governance according to Ansell and Gash that the involvement of actors in 
collaboration is not only the government as a representative of the state but also non-state actors, namely the community in direct decision making, making the concept of institutional design must be directed to be more flexible and complementary. The design of the collaborative management institution is flexible in the development of tourism in the Province of South Sumatra, this was shown by the Provincial Tourism Office in 2018 to revitalize the Kampung Kapitan as a cultural heritage:

We are in building collaboration together with the community, we demonstrated this during the development of the Kapitan village as a Cultural Heritage that has not yet received the touch of the local government. We encourage the people in the captain's village to form a community so that they can officially apply for assistance and we facilitate getting assistance from the Ministry.

The description of the results of the interview above illustrates that with the authority and network it has, local governments should be able to become facilitators to develop tourism objects through their initiatives to manage non-formal institutions to interact and connect. Whereas in institutional design, collaborative management does not have to be required to be established in only formal relationships, but also encouraged to create non-formal relationships so that the connectivity and trust of actors in tourism development can be strong. Their empowerment process through involvement in decision-making, can increase their independence and enable them to take ownership (Binswanger \& Aiyar, 2003) and accountability in the tourism development process.

The foregoing in turn increases the likelihood that the solutions they come up with are supported and implemented locally (Buchy \& Race, 2001). This also happened between government units in the South Sumatra Province, this was revealed by one of the informants that:

In relation to tourism development, we continue to coordinate with Provincial and City district offices, this is done both in the form of formal meetings in the form of Tourism sector development planning meetings, but we also build informal communication to increase networks with other institutions such as the Ministry, Institutions State, Financial Institutions and Airlines.

The above view is in line with Robertson's statement that In order to achieve the goals of economic, social and human development, many diverse stakeholders from the public, private, and not-for-profit sectors must address their conflicts of interest and instead work together to ensure that everyone benefits from the development process. tourism. Individuals and stakeholder groups in the community, who work collaboratively in a special local institutional context, as stated by Research Informants, that:

So there are two things here, the first is to order to embrace stakeholders by collecting and then discussing, but Arifin has thought that here the government must make deals that involve stakeholders with assistance from the government of course, such as the budget, for example, he needs 5 million or 2.5 million from the government.

The statement above, explains that the government with all its strengths can more 
successfully identify the strategies for change needed to achieve the kind of tourism development that the community wants. The development of tourism as one of the goals of driving the people's economy requires the involvement of multi-sectoral and multidimensional stakeholders. This is because the success of a collaboration process is one of the reasons for the wide involvement of actors, as stated by Ansell and Gash "As Chrislip and Larson (1994) wrote, "The first condition of successful collaboration is that it must be broadly inclusive of all stakeholders who are affected by or care about the issue. "This includes potentially" troublesome "stakeholders" (Ansell \& Gash, 2008).

The development design in the tourism process has formally been mandated both in Law Number 10 of 2009 concerning Tourism as a basis for tourism activities, tourism development policies and tourism management are carried out based on the principles of kinship, participatory, fair and equitable. This foundation should also be the basis for the institutional design of tourism development in South Sumatra Province. This is in line with Robertson's view, that:

International entities have been exploring ways to promote and assess progress towards sustainable development in the tourism sector. These efforts have included such features as focusing on social and human development along with economic development goals, recognizing the uniqueness of each country's indigenous culture, and acknowledging the limits imposed by natural resources and the environment. Such efforts have further reflected growing recognition that development processes, to be successful, need to integrate both well-functioning government institutions and free-market mechanisms through the use of cross-sectoral partnerships and networks that enhance the level of stakeholder participation in relevant decision-making processes.

The statement above explains that the process of developing tourism collaboration management begins with awareness in managing the potential that is owned to become a tourist attraction, starting with social and human development first, so that in the tourism development process all actors realize the uniqueness of the original culture of each tourist attraction which is an important capital to be developed and synergized with the potential of natural resources and the environment owned. This needs to be done by integrating local government agencies with tourism actors who make tourism a market through the principles set out in applicable laws and regulations.

Tourism development as a process can be interpreted differently by each actor involved. In designing a tourism development institution, a synergy of the objectives of tourism development must be carried out. Based on the views of various experts, tourism activities in the context of development are closely related to the economic sector, even the economic aspect is the dominant goal of all actors. Actors who also have a role in accelerating tourism development are the media through reported information, besides that the median is also a pending means to build networks in tourism development, this is in accordance with the information submitted, that:

In my opinion, the media's role in tourism can play a bigger role than tourism, right? Yes You 
have to differentiate between good and bad, like Bali, for example, the media in Bali is regulated in such a way as to spread news that is soft or gentle so as to create the thought that Bali is the safest place. It's all just to show the image that Bali is safe and fun.

The tourism sector in several studies found that large networks of business activities in several large countries have a direct relationship with the tourism sector which is obtained from trusted media. This fact explains that indirectly most economic activities are related to tourism activities because of their interdependence on information, because of the interest in implementing collaborative governance between several different business units in creating one of the products related to the carrying capacity of tourism development in Indonesia. a region, a region and even a country.

\section{c. Facilitative Leadership}

The direction of tourism development leading to Community Based Tourism has characteristics consisting of: tourism development by involving local communities to be involved in controlling and managing the tourism development process, even though the community is not directly involved, but benefits from businesses related to tourism development. There is also an empowerment relationship that takes place in a deliberative manner in the distribution of overall benefits to the community. In this regard, active participation from community leaders is needed to become a facilitator in tourism development. This has been mandated in Regional Regulation No. 9 of 2016 article 27 which explains that the Governor through the Office takes action to supervise tourism activities. This indicates that there is full delegation to the agency to supervise and control tourism activities.

Denhardt \& Denhardt have actually been given a strong basis by Arnstein who asserted that citizen participation can be categorized into 3 (three) major parts, namely non-participation, tokenism and citizen power (Arnstein, 2019). Real participation is participation where citizens have the involvement and power to participate and be taken into account in decision making. Collaboration between the government and citizens, both as private economic actors and as the power of civil society, appears in participation in which there is citizen power. Participation in tourism with the concept of citizen power really needs to be controlled with leadership with a soft approach, so that the development of tourism as an industry that is closely related to economic activity can take place conducive.

Citizen power requires leadership to control and control so that there is no bias in the collaborative governance process which has an impact on the achievement of goals. Lake et.al said that leadership has a broad role to describe to all collaboration actors, from the collaboration platform to the achievement of common goals (Lake et al., 2016). The importance of facilitative leadership in collaborative governance is that this leadership is built on skills (Skill). Leadership in the collaborative governance process really requires the ability to understand functions that are interwoven across borders, but the skills in question are based on basic values that are interwoven in collaborative relationships between all the actors involved. 
This is clearly seen in the comparison of leadership to the South Sumatra Provincial Tourism Office from 2015 to 2018 with the leadership of the current Head of Service. Many communities who at that time felt they had a place to be creative and play a role in tourism development are now unable to do much because of the lack of facilitation provided by the Tourism Office for them to play a role. This was clearly expressed by the Research Informants that:

I would like to add that question number one, I think, is very important and has already happened, for example, when Lembang built a skatepark on the Ampera Bridge, it was actually a community idea, but the government did not involve the community at all. But the government made it not according to the standards of the community, even though it was the community that gave the idea. But nothing is associated with the community until the opening time, it doesn't invite the community. Finally, it's been made but don't like the standard so it's useless until now it's also not played by the surrounding environment.

The need for a collaboration platform will be closely related to the media which has a strategic role as a source of information to be taken into consideration for the involvement of various interested actors. In addition, leadership needs to embrace media actors to create a balance in the collaboration process and maintain consistent motivation in the collaborative governance process. This is in line with Chrislip's view which says that:

Civic leaders with new leadership capacities convened citizens and helped facilitate their work. Stakeholders learned new skills for working together and for working with the substance of the issue or concern. Specific tools and consciously designed processes helped them define problems, create visions, and decide what should be done.

The view above, explains that the dreamer's role in facilitating the community to facilitate their activities. Activities of tourists from outside the region in an area will have a meeting of 2 different cultures, this is in line with Yoeti's view which states that: "Tourism with all aspects of life involved in it will demand consequences from the meeting of two or more different cultures, namely the culture of the tourists with the culture of the people around the tourism. By meeting a variety of different cultures, tourism activities will influence various aspects of the life of every actor involved. For this reason, facilitative leadership that always responds to changes found in all actors involved is very much needed to keep the actors directing the goals that have been agreed upon.

In carrying out control over all these actors, transactive planning is needed, the dialogue that occurs is a life dialogue, which is emphasized by Innes and Booher as an authentic dialogue (J. E. Innes \& Booher, 2003). In this case, every actor who sits together respects each other, empathizes, there is a reciprocal and mutually beneficial relationship. Thus, dialogue will only occur if stakeholders participate and sit together in solving problems. The dialogue that is built will create new skills for the community to stay focused on a substantial collaborative governance process.

Participation itself will only occur if they have an interest and have the opportunity to voice 
their interests, and such participation will only occur if there is interdependence and trust. Cooperation through dialogue and participation is directed towards consensus building ( $\mathrm{J}$. Innes \& Booher, 2010; Woltjer, 2000). The process that includes dialogue activities, participation, and is oriented towards joint decisions, is summarized in a collaborative process. The decisions taken are the result of a consciously designed process to assist in creating the Vision and deciding what to do in the collaborative process. The vision in tourism development in South Sumatra Province based on Regional Regulation Number 9 of 2016 is the development of the Creative Economy as one of the supporting elements of tourism development by utilizing intellectual property rights through the provision of creative city facilities and infrastructure based on local potential. However, based on information from research informants that:

We have also dreamed of owning a community house like that of a coffee house for example or like in Bandung the Bandung creative house, Palembang should also have started to build something like that because there we can focus on something that is environmental in nature. Maybe there will be crazier ideas to advance tourism and development in South Sumatra, of course.

Anshell and Gash state that facilitative leadership is a factor that influences the success of a collaborative process (Ansell \& Gash, 2008). They develop a Collaborative Governance model, with a collaborative process as the main element that is influenced by leadership and institutions in achieving the desired results. Meanwhile, Huxham and Vangen conducted research on leadership in the formation and implementation of collaborative agendas, by looking at the role of leadership through the media: structure, process, and participants and observing leadership activities in the collaborative agenda in terms of power management and agenda control (Huxham et al., 2000), representation and mobilization of members of the organization, encouragement and empowerment of members who have the ability to achieve organizational goals.

In this case, Larry Lashway presents about Facilitative Leadership. which in essence is leadership that focuses on collaboration and empowerment. Meanwhile, Boyne et.al define facilitative leadership as: "the behaviors that enhance the collective ability of a school to adapt, solve problems, and improve performance" (Boyne et al., 2004). The key word lies in the collective. This means that successful collaboration is not a result and is determined by individual work, but rather is the work of an intelligent team work.

The Department of Tourism as the leading sector of tourism development in South Sumatra Province has lost a leadership figure in regulating and directing tourism development activities. The loss of direction of the tourism office in tourism development since 2019 is in line with information from informants that:

For the last provincial government, the last activity is to color kindergartens but they don't want to involve the community and use an Event Organizer (EO). But the EO was from yesterday's sponsor, palpers, so his mother was from palpers. Share their food which organizes their event. So what these agencies know is all right, just sign the report and so on. But lately there have been many events from the provincial 
government for tourism, but this activity seems to have to bring in the governor or deputy governor. like tomorrow there is a Siguntang Hill Festival but the governor can't come, the deputy governor replaces him, even the slightest event, for example coloring the governor's kindergarten, must also come, more importantly there is a photo.

The service as the leading sector which should embrace all parties based on this information does not play an active role in moving all parties to collaborate in tourism development, another thing is also shown by Provincial Leaders who have not paid too much attention to tourism development as a forum for socialization and increasing the quality of public awareness in the development of Sumatra Province South.

\section{d. Collaborative Process}

Collaborative synergy between all interested parties in tourism development is needed to carry out the collaboration process, Huxam and Vangen suggest six things; (a) Managing aims (establishing aims, objectives and objectives), (b) Compromise (in the manner and style of work, norms and culture); (c) Communication (communication to foster the same understanding and avoid tragedy of commons; (d) Democracy and equality (clarifying who is involved in equality of decision processes and accountability); (e) Power an Trust (equality and contribution according to capacity and self-control); (f) determination commitment and stamina (commitment to cooperate with determination to continue the agreement (Huxham \& Vangen, 2000).

The six things described above are closely related in the collaboration process, but in this study the collaboration process that will be discussed is focused on the views of Ansell and Gash who reveal that the collaboration process is at the core of all the interaction processes of actors to implement their ideas and ideas through a face-to-face process. face-to-face which is based on mutual belief and commitment through a process of sharing understanding to provide temporary results.

The collaborative governance process is always described as the stage of agreement development which explains how the phases of the collaboration program are carried out starting from the pre-negotiation phase, the negotiation phase, to the program implementation. So that the success of collaboration depends on how the collaboration cycle revolves, starting from communication, building trust, commitment, sharing understanding to the expected results. The importance of understanding the importance of tourism development can raise public awareness to participate in tourism development according to their capacity and ability. This is as stated by the research informants that:

And there's no harm in building tourism because population growth continues to increase and tourism is a necessity, for example, what was the beginning, how is it now? Slowly, many tourists came and the impact on starting from the increase in the income of the surrounding population increased, the mindset of the people themselves increased, starting from the arrangement there is also increasing and the most important marketing continuously does not stop.

The growing awareness in the collaborative process is a process in which there is a dialogue 
that requires the participation of stakeholders, which ultimately results in a mutually agreed decision. Anshell and Gash identify the collaborative process as a cycle that includes: face-to-face dialogue, trust-building, commitment to the commitment to process, shared understanding, and interim results. (intermediate outcomes) (Ansell \& Gash, 2008). Face-to-face dialogue is a negotiation with good faith which is expected to build trust. Next, build a commitment to the process, which is demonstrated by the existence of dependency competitiveness, a sense of ownership of the process, and an openness to explore mutually beneficial things. Sharing understanding is reflected in the existence of a clear mission, common understanding of problems, and identifying shared values. Interim results are expected to be achieved through "small win" strategic planning, as well as combining facts together.

Strategic planning in tourism development will depend on the synergy of planning documents consisting of: Regional Medium-Term Development Plans (RPJMD), Regional Spatial Plans (RTRW) and Regional Tourism Development Master Plans (RIPPDA). Comprehensively, these three documents should have a close relationship to be able to support each other in the administration of governance and regional development as a whole. The problem faced is in the real condition that the actualization of the three planning documents is still sectoral. In this case, each SKPD that is the leading sector must collaborate in the synergy process of implementing the policies of each planning document. The events that occurred were different in South Sumatra Province as revealed by the research informants that:

When we know our priorities, they will be in the national RPJMN. In the next five years, there are seven national priorities out of the seven national priorities that we will elaborate on to the provincial level so that they are adjusted to the vision and mission of the governor that is in the RPJMD. So, there are provincial development priorities, so what's the theme this year? It is adjusted, then a coordination meeting will be held to support the governor's vision and mission to adjust this year's theme and later will connect to Bappenas to adjust this year's national priorities within 3 years.

Observing the information above, it can be found that in the mindset and culture of the government in South Sumatra Province, it is still limiting the process of administering government, especially tourism development to the extent of the time spectrum, term of office and Vision and Mission of Regional Leaders, this is very different from the goal of sustainable development which synergizes the process of governance in one rhythm and one common goal. In the actualization of the joint objectives, it is very necessary to hold meetings to harmonize ideas, ideas and hopes collectively which in fact have been implemented by the Provincial Government of South Sumatra through formal forums as expressed by the Research Informants that:

I see actually the foundation or the system that was made with satay is really good, we have had technical coordination meetings, the coordination meetings at the Regency-City level have all been very good and we invite the parties from the stakeholders. Make sure that what we've been doing so far, there must be shortcomings or not optimal, what we see must be optimized again in the system we've created, in the 
sense that when I saw it first, when there was a meeting, this turned out to be involved, so in the end there must be something missing. in planning and so on, what needs to be improved from that side. what must be improved so that the results we achieve are indeed in accordance with the initial planning.

The face-to-face process is the key word of the collaborative process concept developed by Ansell and Gash, it is based on human nature in building trust which is always on the basis of direct interactions between actors through conversation, eye contact and handshakes. From the explanation given above, it can be seen that the process is indeed correct in that the building of trust is not properly developed due to direct contact between local governments because between the initial planning commitments and the implementation of what has been carried out are often different. The dialogue that was built was only about fulfilling the requirements of government formalities, but the quality of the discussions was not directed so that there was no continuation of commitment. In addition, from the explanation it appears that the forum in which the actors involved are involved is limited to the formal government scope. The involvement of all actors in the collaborative development process should be, in line with the views of research informants that:

So Pentahelix that day had its own directory in the sense of the word South Sumatra, it already knows how many academics are in South Sumatra and have different potentials, how many private private sectors are different, how many mass media when the directory is opened I can analyze it has been mapped so that no more miss control, okay when doing this, what involvement is all already well-indicated (Chen et al., 2015).

The intended directory of the informants above in the collaborative governance process is needed as initial data in the development of discussions to determine the results to be achieved together. Through the shared purpose that was built, it became the motivation for Together to carry out the collaborative management process. Within the framework of this research, tourism development should begin with pride in the tourism potential of the Province of South Sumatra, as revealed by the Research Informants:

Outsiders only see Palembang that is special, when the Palembang people themselves are not proud of Palembang, it gives the impression that they are more proud to go to other areas than to their own area. secondly, if we compare Indonesia's tourism potential with foreign countries, we are also superior to foreign countries.

Building trust is a time-consuming process that requires a long-term commitment to achieve collaborative. Therefore, if history shows antagonism between stakeholders, then policy makers or stakeholders must find time to rebuild trust. If the stakeholders are unable to build trust, a collaborative process will not be possible. A common understanding is needed between the government as regulators and from entrepreneurs as business actors in order to achieve success in tourism development, on the one hand the government has an obligation to pay attention to and ensure that tourism development can provide benefits and reduce socio-economic costs while minimizing environmental impacts. On the other hand, business people who are more focused and profit-oriented certainly can't just do everything to achieve profit. But it must adapt to policies with regulations from the government. For example 
through spatial regulations, licensing, licensing, accreditation, and legislation.

Leadership is central to realizing trust between collaborative actors. If the leader is not able to act as a distributor of commitment and build trust, it will have an impact on separating and moving on their own, the collaborative actors will hinder the collaborative process in the development of cultural tourism in South Sumatra Province. Leadership plays a role in exploring the values of mutual benefit to be able to achieve the commitment of the actors in a collaborative process, so that the existing leadership must be able to encourage mobilizing, facilitating and empowering the actors involved.

Building trust and commitment greatly affects the success rate of collaboration. Because partnership in collaboration can be interpreted as an interaction between the commitment and trust of the actors based on the thought that the actor will not be able to stand alone without the support of other actors. Commitment can only be achieved by accommodating the interests of all parties, and is based on strong commitment and long-term relationships that are continuously fostered. For example, actors must comply with the results of the deliberation as a form of commitment, even though the decision requires joining forces with actors with different views. So, this commitment requires trust so that the responsibilities of each actor can be carried out properly. In this context, commitment to the process is a consequence of the involvement of each member in a collaborative tourism development forum and forging an engagement that requires committed parties to follow the collaborative process as determined.

Building trust in tourism development takes a long time. This is closely related to the repeated proof of the commitment of each actor involved. In terms of building trust, it is very necessary to avoid the arrogance of the actors involved, because the presence of arrogance shown on the authority or potential that is built will hinder the collaborative governance process. This happened in the tourism development of the province of South Sumatra which was explained by the research informants that:

The example of the case in Kampung Almunawar regarding the construction of the pier in the village, maybe the RT agrees with it so the government thinks that the community agrees but in fact there is some resistance that has occurred below which must also be considered. times with the community. So mapping is important.

From the statement above, the government as a regulator and policy maker should position itself wisely and wisely to greet the community to get a public response regarding the policy plan for developing the area so that the design of tourism development can support community development as well. This is closely related to building public trust to foster a sense of ownership and awareness in relation to tourism awareness. In relation to tourism activities, the value of tourism charm really requires community participation, namely: safe, orderly, clean, cool, beautiful, warm and memorable.

Likewise, in managing an affair that involves various stakeholders such as tourism development, understanding relationships will definitely be well established if it is based on a shared vision. Building a vision together can move people as individuals or as part of the 
masses to know and know themselves as part of a group. At some point in the collaborative process, stakeholders must develop a common understanding. Common understanding involves the same mission, commonalities, common goals, common goals, clear objectives, clear and strategic directions, alignment of core values, alignment of problem definitions. In this case, it is necessary to understand the concept of tourism development in the province of South Sumatra.

\section{Closing}

Tourism development has formally mandated to be implemented with a collaborative concept, but in actualization based on the collaborative governance concept presented by Ansell And Gash, it was found that collaborative governance in tourism development with good tourism potential in the Starting Condition has not been supported by institutions that create value and standard norms to support the collaboration process, so that building trust between each actor is not well-established and synergistic to develop tourism in South Sumatra Province. The role of facilitative leadership has not yet been demonstrated by the Tourism and Culture office to make the collaboration process run well in the context of tourism development.

\section{Reference}

Ansell, C., \& Gash, A. (2008). Collaborative governance in theory and practice. Journal of Public Administration Research and Theory, 18(4), 543-571. https://doi.org/10.1093/jopart/mum032

Arnstein, S. R. (2019). A Ladder of Citizen Participation. Journal of the American Planning Association. https://doi.org/10.1080/01944363.2018.1559388

Binswanger, H., \& Aiyar, S. (2003). Scaling up community-driven development : theoretical underpinnings and program design implications.

Boyne, G. A., Gould-Williams, J. S., Law, J., \& Walker, R. M. (2004). Toward the self-evaluating organization? An empirical test of the wildavsky model. Public Administration Review, 64(4), 463-473. https://doi.org/10.1111/j.1540-6210.2004.00392.x

Buchy, M., \& Race, D. (2001). The Twists and Turns of Community Participation in Natural Resource Management in Australia: What Is Missing? Journal of Environmental Planning and Management, 44, 293-308. https://doi.org/10.1080/09640560120046070

Chen, J. K. C., Batchuluun, A., \& Batnasan, J. (2015). Services innovation impact to customer satisfaction and customer value enhancement in airport. Technology in Society. https://doi.org/10.1016/j.techsoc.2015.05.010

Gabriel, L. (2017). Konflik Tata Ruang Kehutanan Dengan Tata Ruang Wilayah (Studi Kasus Penggunaan Kawasan Hutan Tidak Prosedural Untuk Perkebunan Sawit Provinsi Kalimantan Tengah). BHUMI Jurnal Agraria Dan Pertanahan, 3(1), 51-66. https://www.researchgate.net/publication/318511982_Konflik_Tata_Ruang_Kehutanan_Deng an_Tata_Ruang_Wilayah_Studi_Kasus_Penggunaan_Kawasan_Hutan_Tidak_Prosedural_Un tuk_Perkebunan_Sawit_Provinsi_Kalimantan_Tengah 


\section{Macrothink}

Journal of Public Administration and Governance ISSN 2161-7104 2021, Vol. 11, No. 3

Goedner, C. R., \& Ritchie, J. R. B. (2011). Tourism: Principles, Practices, Philosophies (2nd ed.). Wiley.

Huxham, C., \& Vangen, S. (2000). Leadership in the Shaping and Implementation of Collaboration Agendas: How Things Happen in a (Not Quite) Joined-Up World. The Academy of Management Journal, 43. https://doi.org/10.2307/1556343

Huxham, C., Vangen, S., Huxham, C., \& Eden, C. (2000). The Challenge of Collaborative Governance. Public Management Review, 2(3), 337-358. https://doi.org/10.1080/14719030000000021

Innes, J., \& Booher, D. (2010). Planning with Complexity: An Introduction to Collaborative Rationality for Public Policy. In Planning Theory \& Practice (Vol. 11). https://doi.org/10.4324/9780203864302

Innes, J. E., \& Booher, D. E. (2003). Collaborative policymaking: Governance through dialogue. In Deliberative Policy Analysis: Understanding Governance in the Network Society (Vol. 9780521823, pp. 33-59). https://doi.org/10.1017/CBO9780511490934.003

Lake, Q., Page, N., Gitsham, M., MacAlister, J., \& Berman, C. (2016). Corporate leadership on modern slavery: How have companies responded to the Modern Slavery Act one year on? - SUMMARY REPORT. https://doi.org/10.13140/RG.2.2.23079.75689

Maxwell, J. A. (2012). Qualitative Research Design: An Interactive Approach. In SAGE Publication (3rd Editio). SAGE Publication.

Natori, M. (2001). A Guide Book for Tourism-Based Community Development. Asia Pasific Tourism Exchange Center (APTEC).

Peck, J., \& Lepie, A. (1989). Tourism and Development in three North Carolina Coastal Town's in V.L. Smith (ed). In Host and Guest: The Antropologhy of Tourism (p. 216). University of Pennsylvania Press.

Woltjer, J. (2000). Consensus Planning, The Relevance of Communicative Planning Theory in Dutch Infrastructure Development. Ashgate.

\section{Copyright Disclaimer}

Copyright for this article is retained by the author(s), with first publication rights granted to the journal.

This is an open-access article distributed under the terms and conditions of the Creative Commons Attribution license (http://creativecommons.org/licenses/by/4.0/). 